Meta

Journal des traducteurs

Translators' Journal

\title{
Hermeneutic Uncertainty and Prejudice
}

\section{Ineke Wallaert}

Volume 61, numéro 1, mai 2016

Des zones d'incertitudes en traduction

URI : https://id.erudit.org/iderudit/1036988ar

DOI : https://doi.org/10.7202/1036988ar

Aller au sommaire du numéro

\section{Éditeur(s)}

Les Presses de l’Université de Montréal

\section{ISSN}

0026-0452 (imprimé)

1492-1421 (numérique)

Découvrir la revue

\section{Citer cet article}

Wallaert, I. (2016). Hermeneutic Uncertainty and Prejudice. Meta, 61(1), 165-186. https://doi.org/10.7202/1036988ar

\section{Résumé de l'article}

L'incertitude herméneutique fait partie intégrante de l'art du traduire, et ses conséquences sont un aspect inéluctable de ses produits. Dans le présent article, nous soutenons que l'enseignement et la pratique de la traduction n'échappent pas à la responsabilité sociale qui consiste à déclarer clairement l'existence de l'incertitude herméneutique et à en reconnaître les tenants dans la pratique traductive. Nous montrons comment l'herméneutique heideggérienne a mené Gadamer vers le concept de préjugé(s)

herméneutique(s) et nous démontrons que la description philosophique des fonctionnements de ce(s) préjugé(s) peut constituer un outil pédagogique dont les enseignants en traduction peuvent se servir afin d'aider leurs étudiants à traiter des éléments ambigus ou difficiles du texte source avec plus de confiance. Cette prise de conscience herméneutique peut également s'appliquer à des traductions publiées, où elle peut être testée dans sa capacité de révéler comment certains traducteurs ont géré des cas spécifiques d'incertitude herméneutique. L'exemple étudié ici est une paire de termes qui figurent dans Die Aufgabe des Übersetzers de Walter Benjamin, un essai choisi pour son ubiquité dans le domaine de la traductologie. Analyser comment les traductions françaises et anglaises diffèrent dans leur traitement de cette difficulté herméneutique servira ici à examiner à quel point les traducteurs sont prêts à reconnaître (ou à ignorer) des cas d'incertitude herméneutique, en donnant ou en refusant à cette dernière une place dans leurs traductions.
Ce document est protégé par la loi sur le droit d'auteur. L’utilisation des services d’Érudit (y compris la reproduction) est assujettie à sa politique d'utilisation que vous pouvez consulter en ligne.

https://apropos.erudit.org/fr/usagers/politique-dutilisation/ 


\title{
Hermeneutic Uncertainty and Prejudice
}

\author{
INEKE WALLAERT \\ Université de Caen, Caen, France \\ ineke.wallaert@unicaen.fr
}

\section{RÉSUMÉ}

L'incertitude herméneutique fait partie intégrante de l'art du traduire, et ses conséquences sont un aspect inéluctable de ses produits. Dans le présent article, nous soutenons que l'enseignement et la pratique de la traduction n'échappent pas à la responsabilité sociale qui consiste à déclarer clairement l'existence de l'incertitude herméneutique et à en reconnaître les tenants dans la pratique traductive. Nous montrons comment l'herméneutique heideggérienne a mené Gadamer vers le concept de préjugé(s) herméneutique(s) et nous démontrons que la description philosophique des fonctionnements de ce(s) préjugé(s) peut constituer un outil pédagogique dont les enseignants en traduction peuvent se servir afin d'aider leurs étudiants à traiter des éléments ambigus ou difficiles du texte source avec plus de confiance. Cette prise de conscience herméneutique peut également s'appliquer à des traductions publiées, où elle peut être testée dans sa capacité de révéler comment certains traducteurs ont géré des cas spécifiques d'incertitude herméneutique. L'exemple étudié ici est une paire de termes qui figurent dans Die Aufgabe des Übersetzers de Walter Benjamin, un essai choisi pour son ubiquité dans le domaine de la traductologie. Analyser comment les traductions françaises et anglaises diffèrent dans leur traitement de cette difficulté herméneutique servira ici à examiner à quel point les traducteurs sont prêts à reconnaître (ou à ignorer) des cas d'incertitude herméneutique, en donnant ou en refusant à cette dernière une place dans leurs traductions.

\begin{abstract}
Hermeneutic uncertainty is an inherent part of the art of translation, and its consequences are ineluctable features of translation products. In this article I support the claim that the teaching and practice of translation do not escape the social responsibility which resides in clearly declaring and acknowledging the existence of hermeneutic uncertainty. Investigating how Heideggerian hermeneutics led to Gadamer's development of the concept of hermeneutic prejudice. I will show that the philosophical description of how this prejudice functions can be a useful part of the pedagogical materials presented by translation teachers, and can help students to approach ambiguous or difficult source text elements more confidently. Such hermeneutic consciousness-raising can also be applied to published translations, where it can be tested to reveal how translators have dealt with specific instances of hermeneutic uncertainty. The case studied here is a pair of terms occurring in Walter Benjamin's Die Aufgabe des Übersetzers, chosen mainly for its ubiquitous presence in the field of translation studies. The story of how French and English translations differ in their understanding of this specific hermeneutic difficulty will be used to investigate the extent to which translators acknowledge (or ignore) the existence of hermeneutic uncertainty by allowing it to enter their translations or by discarding it from them.
\end{abstract}

\section{MOTS-CLÉS/KEYWORDS}

préjugé, incertitude, Hans Georg Gadamer, Walter Benjamin, traductologie prejudice, uncertainty, Hans Georg Gadamer, Walter Benjamin, Translation Studies 
Brave is the thief who carries a lamp in his hand.

(Shah 1968: 178)

\section{Introduction}

Richard Feynman, considered by many as the greatest physicist of all time, worked during a period that saw the end of the very laws of physics, and was powerfully aware that uncertainty itself is the pillar of scientific inquiry. In a well-known public address delivered to the Academy of Science in 1955 Feynman insisted on the importance of this by referring to our ability to question and doubt as the "open channel" (Feynman 1955: 15) through which mankind might realise its full potential, or at least move in a direction that might one day lead to such an achievement. Feynman thus asked his audience to allow for a sense of doubt and uncertainty to pervade any type of inquiry as a fundamental necessity, explaining that

[...] freedom to doubt was born of a struggle against authority in the early days of science. It was a very deep and strong struggle. Permit us to question - to doubt, that's all - not to be sure. And I think it is important that we do not forget the importance of this struggle and thus perhaps lose what we have gained. Here lies a responsibility to society. (Feynman 1955: 14-15)

It would seem obvious that acknowledging the existence of all-pervading uncertainty is a social responsibility, and that denying or disguising its ubiquity is unsound and irresponsible. Still, though people in general are becoming more and more aware that the future is uncertain, both on a global politico-economic level and on the more practical levels of the environment, of technology and of the socio-cultural structure of our societies, the educational institutions that shape our societies' knowledge and know-how unfortunately do not abound with people who will loudly proclaim that the only thing they know is that they don't know anything for certain.

\subsection{The institutionalised denial of uncertainty in translation}

The field of Translation Studies is not exactly flooded with testimonies in which translators detail their incapacity to determine in a permanent way the meaning of this or that source-text element. What is more, most teachers of translation seem to underestimate the importance of blatantly recognising that in spite of years of training and research, translators are always faced with uncertainty when they try to figure out the meaning of language in discourse. Nor do they acknowledge that it is their social responsibility to present this to their students as a natural part of translation. Indeed, though we all know that if language were a precise and unambiguous phenomenon, machine translation would already have put us all out of a job, we continue to create the impression that between two closely related interpretations, one alternative is always more correct than the other. To this we might add the fact that in countries like France, translation classes at undergraduate level are geared towards the national teaching exams (for example the CAPES ${ }^{1}$ and Agrégation exams) which steer students towards norms of fluency and standardised translations (that is, those proposed by the members of the jury). Such standardised testing aimed at preparing students to pass national exams obviously does not leave much room for any notions of uncertainty in the minds of either translator trainers or their students. 
Apart from habitually presenting students with model translations, many teachers also find the ultimate proof of the supposed correctness of a translation choice in the fact that a translation is published and therefore the official standard, as if anything that is printed is automatically truthful, and presuming that editors, publishers and reviewers always apply the same qualitative standards to the translations they publish as translation teachers use when evaluating their students' assignments. The fact that many reviewers continue to allow themselves the luxury of commenting on the quality of a translation without having access to the source text is a clear sign that there is a genuine refusal to recognise that the translation process is by nature fraught with uncertainty.

\subsection{The importance of tinkering}

Feynman's philosophy and work methods also teach us that discoveries are made, and understanding is created, through a process which Feynman's biographer appropriately refers to as "the art of tinkering" (Gleick 1992: 17), that is, the idea that scientific discoveries happen through trial, error, and retrial, or in other words, through a process of submitting the object of study to a series of tests that are aimed at answering the question: "What happens if I do this?" The analogy with translation is that we often settle on a solution after having tried a set of possibilities, asking ourselves: "How does this apply in the context of this line/paragraph/text?" Translating is tinkering with language in discourse, and a good tinkerer leaves room for surprises and changes in strategy, and expects to be faced with unknown or unfamiliar elements. In other words, the first step in tinkering with language in the exercise of translation is to acknowledge the reality of hermeneutic uncertainty.

\subsection{Why bother?}

Most postgraduates of translation courses in mainland Europe, especially those who follow a professionalising course (as opposed to a research-centred course) complete their study programme with an internship ata translation agency, be it private or public. This first professional experience fills many students with anxiety: they are rightfully concerned about the quality of the translations they are asked to do, since the internship often constitutes the levy of their subsequent entry on the labour market. I asked some of my graduate students at Strasbourg University to find the one word which would describe how they had experienced the moment(s) when, during these internships, they had found themselves faced with an element in the source text which at first left them clueless. The words they came up with most often during this informal survey, which was conducted in English, were stress, anxiety and a feeling of being stuck, with the first two terms being the ones everyone seemed to agree upon. I realised that I had failed at the task of equipping these young translators with the necessary mental resources to face the demands of their future profession. Had their consciousness been more strongly permeated with the fact that hermeneutic uncertainty is the reality of translation, they might have come up with more positive terms such as excitement, surprise, challenge, or even confidence. This practical observation further supports my claim that it is important to acknowledge hermeneutic uncertainty more clearly, and that as translator 
trainers we should integrate discussions of it in our translation practice and theory classes.

\subsection{How can one describe hermeneutic uncertainty?}

There is a great deal of recent research in cognitive psychology on the mental processes underlying insight and understanding, and studies that focus on these aspects of understanding will of course constitute a very useful starting point to investigate hermeneutic uncertainty. For the purposes of this paper the observation made in cognitive psychology that insight is far better achieved when people are in a positive frame of mind, is of course extremely relevant. It should not come as much of a surprise that recent studies using fMRI (functional magnetic resonance imaging) bear out this psychological mechanism, showing that when people feel confident and positive (whether these states are induced or not), instead of feeling anxious, they will perform better on insight and creative problem solving tasks. This is confirmed by Subramaniam, Kounios et al., who cite an impressive amount of research which proves that "PA [positive affect] has been shown to facilitate insight and creative problem solving across a broad range of settings," while "anxiety in particular should impede cognitive flexibility, problem restructuring, and insight solving" (Subramaniam, Kounios et al. 2008: 3).

Though this insight from cognitive psychology backs up my contention that the issue of uncertainty should be addressed before our graduates hit the labour market, and while Stolze confirms that there are links to be established between the study of "the multifarious outreach of the human mind, or the constructive process of knowledge creation" and hermeneutics (Stolze 2010: 145), I will here leave further considerations emanating from cognitive psychology aside, and focus solely on philosophical descriptions of hermeneutic uncertainty. The main reasons for this choice are that first, a philosophical approach allows me to better discern the precise object of study I want to tackle here, and second, there is the usual lack of space. Moreover, Heideggerian and post-Heideggerian hermeneutics present a positive and constructive description of what comes into play when we are faced with hermeneutic uncertainty, a positivity which is confirmed (and completed) by recent findings in cognitive psychological research on subjectivity, motivation, insight and the nature of understanding.

\section{Objectives}

Hermeneutic uncertainty is an inherent part of the art of translation and its consequences are ineluctable features of its products. In what follows I will therefore support the claim that the teaching and practice of translation do not escape the social responsibility which resides in clearly declaring and acknowledging the existence of hermeneutic uncertainty and that practitioners and teachers of translation can do more to make their readers and students aware that hermeneutic uncertainty is a pervasive fact of modern life and a fundamental characteristic of translation.

To this end I will show, firstly, how a discussion on the topic of hermeneutic uncertainty might be integrated into translation theory courses, by presenting the highly instructive concept of prejudice as developed by the German philosopher Hans 
Georg Gadamer. The philosophical description of how hermeneutic prejudice functions in our understanding of ambiguous or otherwise difficult elements in translation is a way of acknowledging its existence, and defining its nature and analysing its effects can be a useful part of the pedagogical materials presented by teachers of translation and translation theory classes.

Secondly, I will show how hermeneutic consciousness-raising may also be taken out into the field of published translations, in order to be tested on how translators and editors of translations have dealt with specific instances of hermeneutic uncertainty. The case studied here is Walter Benjamin's Die Aufgabe des Übersetzers (1923), and the story of how French and English translations differ on their understanding of a specific hermeneutic difficulty will be used to investigate the extent to which translators acknowledge or ignore the existence of hermeneutic uncertainty by allowing it to enter their translations. The example is chosen purposefully due to the enormous prestige of the essay in which it features because this increases the likelihood that readers will be familiar with the specific hermeneutic issue discussed here. The recent debate surrounding the reading of Benjamin's essay in translation theory classes also makes it a slippery and therefore appropriate testing ground for my affirmation that it is time translators and translation teachers took a more positive pedagogical stance towards hermeneutic uncertainty.

\section{Pre-hermeneutic uncertainty}

The notion of hermeneutic uncertainty can be applied both to how we understand the source text and to how we decide how to best translate it into the target language, and for the purposes of this article, the term needs some fine-tuning. The theoretical investigations will here be limited to the first tier or layer of understanding, since we will focus solely on how we understand source text meaning. A more specific term for the object of study is therefore needed here, and the choice of words and concepts requires some explanation.

\subsection{The Eh? Moment}

In order to describe the part of the translation process which I want to focus on, we can start from what psychologists have called the "Aha! moment," which is a "sudden comprehension that solves a problem, reinterprets a situation, explains a joke, or resolves an ambiguous percept" (Kounios and Beeman 2009: 210), in other words, the moment of total comprehension or insight. The hermeneutic moment I here want to examine is at the opposite end of the insight scale, at its beginning: it is the first moment of incomprehension, the first encounter with the problematic meaningful element, the first step in the hermeneutic process. It is the moment when we think "What (on earth) does this mean?" or "What is this doing here?" We might playfully call this the "Eh? moment," or more seriously, the moment of pre-hermeneutic uncertainty. In this moment, as it is our first encounter with the meaningful element, we have not yet begun to try to understand, but there are already a number of things that will affect how the hermeneutic process unfolds in our minds. 


\subsection{Philosophical hermeneutics on pre-hermeneutic uncertainty}

\subsubsection{Pre-Heideggerian hermeneutics}

In a definition featuring in the Oxford Dictionary of English, hermeneutics is "the branch of knowledge that deals with interpretation, especially of the Bible or literary texts," ${ }^{2}$ so generally speaking hermeneutics refers to theories of understanding that underlie the methods by which we interpret data and texts. When the human sciences became academic disciplines in their own right, methods of interpretation for these new branches of science became necessary, and scholars like Schleiermacher or Dilthey worked to determine an approach or a methodology that could guarantee the truth of findings in the human sciences, in particular history. Thus, as Stolze explains, "For the purposes of backing up one's interpretation of a text to expound its meaning, Schleiermacher established several alternative antinomies of analysis as a method." (Stolze 2010: 142). By opposing concepts like "objectivity and subjectivity, analysis and evidence, [...] proof and argumentation" (Stolze 2010: 142), Schleiermacher aimed to arrive at an objective method that would guarantee irrefutability in the same ways as the empirical method had done for the "hard" sciences. However, Schleiermacher's perspective inevitably entailed a prescriptive, rather than a descriptive, approach to understanding, ignoring the fact that the study of human understanding as a universal mental process cannot be successful when it is submitted to pre-established criteria.

\subsubsection{Heideggerian hermeneutics}

When Heidegger tackled hermeneutics in Being and Time, the idea was not to find the right method to guide interpretation, or to define the criteria by which understanding should happen, but to observe how interpretation happens and to describe this as objectively as possible. Thus, from Heidegger onwards, hermeneutics is no longer "a prescription for the practice of understanding, but a description of the way interpretive understanding is achieved" (Gadamer 2004: 269).

Heidegger elaborated the concept of the interpretive circle, which was already understood in ancient rhetoric and now pervades contemporary linguistics in turn, and which refers to the fact, that "we must understand the whole in terms of the detail and the detail in terms of the whole" (Gadamer 2004: 291). In the study of language in discourse this means that the understanding of elements of language elements in a text is based on a back and forth between individual elements in the text and the text as a whole. Heidegger's description of the hermeneutic circle gives the concept a completely new meaning, since for Heidegger this is the occasion to reveal a "hidden possibility of the most primordial kind of knowing” (Heidegger 2008: 195). As Gadamer explains,

The point of Heidegger's hermeneutical reflection is not so much to prove that there is a circle as to show that this circle possesses an ontologically positive significance. (Gadamer 2004: 269)

This positivity lies in the fact that at the beginning there is already something there, a possibility which is neither negative nor positive, as in Heidegger's view, understanding is based on pre-conception(s) or pre-understanding, which Heidegger also calls "fore-having" or "fore-conception" (Heidegger 2008: 191), and whose presence he describes as follows: 
In every case interpretation is grounded in something we see in advance - in a fore-sight. This fore-sight 'takes the first cut' out of what has been taken into our fore-having, and it does so with a view to a definite way in which this can be interpreted. (Heidegger 2008: 191)

This means that the back-and-forth movement of the hermeneutic circle happens between fore-conceptions that dwell in the interpreting being's mind on the one hand, and interpretations which emerge as understanding deepens on the other hand, while both happen with the aim of achieving a (more) definite understanding of what is to be interpreted. As Heidegger says, whether there is already partial understanding at the outset or whether the entity to be understood is still completely "veiled,"

In either case, the interpretation has already decided for a definite way of conceiving it, either with finality or with reservations; it is grounded in something we grasp in advance - in a fore-conception. Whenever something is interpreted as something, the interpretation will be founded essentially upon fore-having, fore-sight, and foreconception. An interpretation is never a presuppositionless apprehending of something presented to us. (Heidegger 2008: 191-192)

It might be tempting to visualise the hermeneutic movement as an ever-expanding diameter of an ever-expanding circle or as a ripple effect but this picture is not entirely adequate, since not only is the movement a to-and-fro between preceding and subsequent understanding, but Heideggerian hermeneutics posits that there is no real beginning or origin to the circle. Mulhall describes Heidegger's views as presented in Being and Time in the following terms:

[...] interpretations generally move within a hermeneutic circle. But this means not just that there can be no interpretation-free point at which to commence the hermeneutic task, but also that there can be no definite end to it. (Mulhall 1996: 194)

The fact that there is neither starting point nor endpoint to understanding and interpretation is a fundamental element of Heidegger's hermeneutics on which Gadamer subsequently draws. Still, understanding must begin somewhere - and this "somewhere" is what Heidegger calls "fore-structures" or "pre-conceptions" (Heidegger 2008: 151-152).

As Gadamer reflects, "The description as such will be obvious to every interpreter who knows what he is about" (Gadamer 2004: 269), and can be easily understood by an undergraduate student. The important thing to remember about Heidegger's forestructures is that

[...] our first, last and constant task in interpreting is never to allow our fore-having, fore-sight, and fore-conception to be presented to us by fancies and popular conceptions, but rather to make the scientific theme secure by working out these fore-structures in terms of the things themselves. (Heidegger 2008: 195)

This point is further elaborated and explained by Gadamer, to whom we now turn.

\subsubsection{Gadamer's hermeneutics}

In Truth and Method Gadamer takes up and develops Heidegger's hermeneutics, showing how it can be usefully and practically applied both to the hermeneutic process and in the shaping of a hermeneutic methodology: 
Methodologically conscious understanding will be concerned not merely to form anticipatory ideas, but to make them conscious, so as to check them and thus acquire right understanding from the things themselves. This is what Heidegger means when he talks about making our scientific theme "secure" by deriving our fore-having, foresight and fore-conception from the things themselves. (Gadamer 2004: 272)

But Gadamer not only warns against "arbitrary fancies and the limitations imposed by imperceptible habits of thought" (Gadamer 2004: 269), he also proceeds to further elaborate a description of the nature of Heidegger's "fore-conceptions." Indeed, as Gadamer explains, in the hermeneutic movement fore-structures are continually completed or supplemented with additional and renewed understandings:

A person who is trying to understand a text is always projecting. He projects a meaning for the text as a whole as soon as some initial meaning emerges in the text. (Gadamer 2004: 269)

This implies that fore-projections which emerge at the outset of the interpretive process might be arbitrary, but if they are, they are discarded as soon as their validity is refuted, and interpretation therefore really happens on the basis of fore-projections that are not arbitrary. From this Gadamer concludes that

it is quite right for the interpreter not to approach the text directly, relying solely on the fore-meaning already available to him, but rather explicitly to examine the legitimacy - i.e., the origin and validity - of the fore-meanings dwelling within him. (Gadamer 2004: 270)

This means, in Gadamer's words, that “The hermeneutical task becomes itself a questioning of things" because

[a] person trying to understand something will not resign himself from the start to relying on his own accidental fore-meanings, ignoring as consistently and stubbornly as possible the actual meaning of the text until the latter becomes so persistently audible that it breaks through what the interpreter imagines it to be. (Gadamer 2004: 271)

It also means that the person is ready to perceive with an open mind the unfamiliar and the unknown, in other words, the text's alterity. That this is not an impossible task or an abstract idealistic view of interpretation is confirmed when Gadamer repeats that the necessary mindset "involves neither 'neutrality' with respect to content nor the extinction of one's self, but the foregrounding and appropriation of one's own fore-meanings and prejudices" (Gadamer 2004: 271).

\subsubsection{Gadamer's prejudice}

It is with the term prejudice that Gadamer couches Heidegger's fore-structures in a more accessible and eloquent terminology, and in order to do so he reminds us that the word prejudice has not always had the negative connotation it has today, and that "Actually "prejudice" means a judgment that is rendered before all the elements that determine a situation have been finally examined" (Gadamer 2004: 273). Gadamer explains that the term has obtained its negative connotation only since the Enlightenment, but that it should no longer be limited to its post-Enlightenment meaning of "unfounded judgment," because 
The negative consequence depends precisely on the positive validity, the value of the provisional decision as a prejudgment, like that of any precedent. Thus "prejudice" certainly does not necessarily mean a false judgment, but part of the idea is that it can have either a positive or a negative value. (Gadamer 2004: 273)

As Gadamer points out, the Latin praejudicium refers both to positive and negative preceding judgments, and as the Dutch word vooroordeel, "The German Vorurteil, like the English 'prejudice' and even more than the French préjugé, seems to have been limited in its meaning by the Enlightenment critique of religion simply to the sense of an 'unfounded judgment."' (Gadamer 2004: 273). Unfortunately, says Gadamer, when we discarded the concept of prejudice we threw out the baby with the bathwater, since we thereby also began to disregard the possibility of their being another type of certainty that is there, even if it apparently "has no foundation in the things themselves, i.e., that it is 'unfounded." (Gadamer 2004: 273). This became problematic for the search for a method of interpretation in the human sciences, as "the rule of Cartesian doubt, accepting nothing as certain that can in any way be doubted" may work for science, but is "difficult to harmonize" (Gadamer 2004: 273) in other fields of human knowledge.

Investigating the fundamental meaning of the term prejudice thus not only sheds light on the positive value of Heidegger's notion of fore-conception, but also reveals the whole nature of pre-hermeneutic understanding, and for Gadamer it is by reconsidering the concept of prejudice that we can begin to "turn those negative statements into positive ones" (Gadamer 2004: 273). In fact, Gadamer states that a review of the concept of prejudice must be the starting point of his own project of hermeneutics:

The prejudices and fore-meanings that occupy the interpreter's consciousness are not at his free disposal. He cannot separate in advance the productive prejudices that enable understanding from the prejudices that hinder it and lead to misunderstanding. Rather, this separation must take place in the process of understanding itself, and hence hermeneutics must ask how that happens. (Gadamer 2004: 295)

Since pre-hermeneutic uncertainty in particular is the moment when the role of fore-projections is most important and, at the same time, when these are most likely to seem arbitrary, examining how the meaning of the term prejudice has changed over time can be a constructive way of helping students of translation realise that, as they are faced with a hermeneutical problem in a source text, their minds will present them with a number of fore-conceptions, some of which they will discard, others which they will build upon, but that whatever their nature, fore-conceptions and prejudices are ontologically present in any interpreter's mind and are an integral and fundamental part of the interpretive process. This awareness also entails that the experience of not having a clue and finding only arbitrary answers, some of which may make sense later on while others will be forgotten, can be positively approached as a first step in the process of dealing with hermeneutic uncertainty.

\subsubsection{Philosophical extensions}

In a course that introduces philosophical theories on the nature of understanding, the hermeneutic circle or motion may also be placed in a wider philosophical context. The horizontal expansion of fore-projections replacing preceding fore-projections might, for instance, be compared to the dynamics of Derrida's concept of the supplement, 
by which Derrida refers to the fact that each (original) text is already a supplement of an indefinite number of other texts. The direct link between this supplementary movement of texts and the nature of translation is laid out more specifically in Des tours de Babel (1987) where Derrida refers to Benjamin's kinship of languages as a "supplémentarité linguistique" of languages reviving and regenerating each other through translation (Derrida 1987: 233). With his concept of the supplement Derrida is also "weaving together the two significations of supplementarity - substitution and accretion" (Derrida 1997: 200), and for Derrida the supplementary nature of translations (he talks at one point about "la structure de supplémentarité dans la traduction" (Derrida 1990: 373)), and of (re)writing in general, implies that the supplement, whether it refers to translations or to languages coming into contact through translation, is additional and expansive, not subordinate, to what precedes it. This might be compared to the movement of the hermeneutic circle as defined by Heidegger and Gadamer, where additional projections and understandings complete and/or substitute preceding ones. Moreover, Derrida posits the origin(al) "under erasure," (Spivak 1997: xv), which implies that the idea of an "originary supplement" is a necessary absurdity (Derrida 1997: 312), and which also implies, in hermeneutical terms, that there is always already a fore-structure that is present and absent, or positive and negative at the same time.

\section{Investigating a case of hermeneutic uncertainty}

\section{1. "Die Aufgabe des Übersetzers" - again}

I will now attempt to show how these insights from philosophy and hermeneutics can be used to describe not only our mental processes during translation practice, but also as a research perspective through which we may study a particular translation problem. The case chosen here features in Walter Benjamin's Die Aufgabe des Übersetzers.

The pervasive presence of Benjamin's essay in translation theory courses and in anthologies and readers has recently undergone criticism from a number of scholars whose complaints mainly result from the fact that Benjamin's essay suffers from over-canonization in every sense of the word. Indeed the essay is too often read as a meaningful text on translation rather than as a collection of ruminations on the messianic role of translation from an early $20^{\text {th }}$ century philosopher with a strong penchant for German Romanticism. ${ }^{3}$ There is some irony in this, because, as Susan Ingram writes, referring to Henning Ritter's remarks on the tendency to synchronically interpret rather than historically contextualize Benjamin's essay,

[t] he tendency to reverence, to concomitant redemption and destruction, to the disturbingly easy canonization of both translation and criticism which characterizes the story of "The Task of the Translator," may underlie the relations between original and translation underwritten by Benjamin's translation essay but it does so in a way as to allow, challenge and demand of critics a level of hermeneutic suspicion and self-reflection to counterbalance the tendencies with respect to which Ritter is so negative. (Ingram 1997: 221-222)

Uncritical contemporary interpretations of the text, which are those Henning Ritter criticized, clearly ignore the fact that at the core of the essay lies a metaphysi- 
cal or transcendentalist view of language, translations and literature that leads to an anachronistically idealistic view of the role of translation and of what translating translators are doing. Still, as I indicated above, the prestige of the essay makes it an appropriate testing ground for the concept of pre-hermeneutic prejudice presented above, since its resulting international diffusion has given rise to three English translations and two French translations of it. What follows is therefore not another exercise in Benjamania but an application of insights from philosophical hermeneutics to the translation choices of four translators dealing with the same source of uncertainty in the same text. Some explanations of the ideas developed by Benjamin in Die Aufgabe des Übersetzers will, however, be necessary in order to highlight the importance of the hermeneutic problem the translators were faced with, and to reveal how their choices may also have affected the reading of Benjamin's text in English and French. One prominent source of information used here is Derrida's comments on the essay, since, as we will also see, these were directly affected by the translation choices which feature in the French version he relied on.

\subsection{Bibliographical information on the French and English translations}

The translation of Benjamin's essay which Derrida refers to was made by Maurice de Gandillac, a philosopher and professor at the Sorbonne. De Gandillac was the first to translate Benjamin into French, and his translations came out as the first part of an edition of selected work by Benjamin, entitled Mythe et violence and published by Denoel in the collection Les Lettres Nouvelles (1971), which is now a branch of Gallimard. In 2000 de Gandillac's translations were republished and completed with other translations and texts of Benjamin's in a "complete works" edition published by Gallimard.

The second French translation of Benjamin's essay is by Martine Broda (1991), a French poet, philosopher and literary critic, who was one of the first women to join the editorial board of the review Action poétique. Apart from Benjamin's essay Broda translated poetry, both into French and into German, wrote critical and philosophical reviews, and published an important amount of her own lyrical poetry. ${ }^{4}$

As for the English translations of Benjamin's essay, the canonical version which is the most widely read and diffused is Harry Zohn's 1992 translation. Zohn was a translator from German, a specialist of Austrian and German Jewish literature, and a Professor at Brandeis University. Lastly, the second English translation we will here refer to is Steven Rendall's, who is a highly prolific and prize-winning translator from French and German, and a former Oregon University professor.

\subsection{From reine Sprache to Überleben and Fortleben}

Our analysis will focus on the pair of terms Überleben and Fortleben, and we therefore need to begin with Benjamin's concept of pure language, which he referred to in "Die Aufgabe des Übersetzers" as "reine Sprache" (Benjamin 1955: 54). Benjamin thought that languages are related to each other by an intention which underlies the combination of all their "modes of intention," and which he called "pure language" (Benjamin 1992: 75). This underlying intention is not a communicative function, nor is it what structural linguistics understands by semiosis. Instead the concept - to 
which Bellos ironically refers as "true-speak" (Bellos 2010: 6) - refers to a transcendental language which will supposedly emerge as translation leads all languages towards a "kinship" (Benjamin 1992: 75) (in German Verwantschaft; Benjamin 1955: 54) that exists between them as modes of intention. Today this messianic view of language strikes readers as translational creationism, because, as Bellos puts it, "Belief in the existence of a transcendent form of human expression - pure language - is really just the same as believing in God" (Bellos 2010: 8).

Still, the concept of pure language is the pillar of Benjamin's view on translation, and before moving on to the hermeneutic problem linked to the concept of reine Sprache we should therefore consult Derrida, who clarifies the connection between reine Sprache and the Überleben or Fortleben of a text through translation. Derrida's reading, based on de Gandillac's 1971 translation, shows that the dominant idea of Benjamin's essay is that translation is the repayment of human beings' debt to God, and he points to the fact that this debt is incorporated in the nature of an original text's aspiring for translation. For Benjamin the relationship between texts-to-betranslated and their translations is thus like "le rapport de la vie à la survie" (Derrida 1987: 216), and a translation can therefore "save" a text from death, but it can only do so for a text that carries the requirement for translation within itself, as a given:

En ce sens la dimension survivante est un a priori - et la mort n'y changerait rien. Pas plus qu'à l'exigence (Forderung) qui traverse l'œuvre originale et à laquelle seule peut répondre ou correspondre (entsprechen) "une pensée de Dieu." La traduction, le désir de traduction n'est pas pensable sans cette correspondance avec une pensée de Dieu. (Derrida 1987: 217)

In Benjamin's essay the "continuing life" (Rendall 1997: 153) of texts through translation is thus a central concept, directly related to the messianic notion that there is a higher realm of pure language for texts to rise to. In other words, the survival Benjamin talks of when he's using the terms Überleben and Fortleben is the living-on of texts through translation, and of literatures and languages through the establishment of a kinship between languages which results in pure language.

One of the remarks which Derrida makes in Des tours de Babel is therefore that in La tâche du traducteur, Benjamin "circule sans cesse entre les valeurs de semence, de vie et surtout de "survie" (Überleben a ici un rapport essentiel avec Übersetzen)" (Derrida 1987: 213-214) and that

Telle survie donne un plus de vie, plus qu'une survivance. L'œuvre ne vit pas seulement plus longtemps, elle vit plus et mieux, au-dessus des moyens de son auteur. (Derrida 1987: 214)

But the metaphysical nature of this continuing life is carried forward by Derrida for whom Benjamin's Überleben (or de Gandillac's translation of it) refers to a "higher" form of survival. Derrida therefore highlights that Benjamin's essay uses the two terms to designate the idea of survival:

At times he [Benjamin] says "Überleben" and at other times "Fortleben." These two words do not mean the same thing ("Überleben" means above life and therefore survival as something rising above life; "Fortleben" means survival in the sense of something prolonging life), even though they are translated in French by the one word "survivre," which already poses a problem. (Derrida 1985: 122) 
That Derrida's reading is influenced by the choices of de Gandillac, whose version he consulted, becomes clear when a closer look at the original version of Benjamin's essay reveals that Benjamin does not "at times" use one term and "at other times" the other. Out of nine occurrences, Benjamin only opts for Überleben once, and when he does so, he even indicates that this choice is particular (though he does not explain its particularity) by putting the term between quotation marks: "Zwar nicht aus seinem Leben so sehr denn aus seinem > Überleben<" (Benjamin 1955: 51). In all the other cases where the idea of "continuing life" occurs, Benjamin opts for Fortleben. Even when he talks about the "eternal" afterlife of texts, Benjamin still opts for Fortleben in both instances: "ihres grundsätlich ewigen Fortlebens" (Benjamin 1955: 52), and "am ewigen Fortleben der Werke" (Benjamin 1955: 55). The translation of the difference between the two terms which we are about to study can therefore be said to have had critical and meta-critical consequences.

To sum up, the hermeneutic problem I'd like to address in Benjamin's text is whether and how four of its translators have understood, and subsequently translated, the difference between the German Überleben and Fortleben. Below are all the passages in which Benjamin uses either Überleben or Fortleben, presented in their context first, and subsequently summarized in a table for greater ease of following the analysis of the four translators' respective choices.

\subsection{Examples and extracts}

\subsubsection{Case 1}

(1) So wie die Äußerungen des Lebens innigst mit dem Lebendigen zusammenhängen, ohne ihm etwas zu bedeuten, geht die Übersetzung aus dem Original hervor. Zwar nicht aus seinem Leben so sehr denn aus seinem > Überleben $<$.

(Benjamin 1955: 51; our emphasis ${ }^{5}$

(a) De même que les manifestations de la vie, sans rien signifier pour le vivant, sont avec lui dans la plus intime corrélation, ainsi la traduction procède de l'original. Certes moins de sa vie que de sa «survie».

(Benjamin 2000a: 246; Translated by Maurice de Gandillac)

(b) Tout comme les manifestations de la vie sont en corrélation intime avec le vivant sans rien signifier pour lui, la traduction surgit de l'original. Non pas tant, à dire vrai, de sa vie que de sa «survie».

(Benjamin 1991: 152; Translated by Martine Broda)

(c) Just as the manifestations of life are intimately connected with the phenomenon of life without being of importance to it, a translation issues from the original - not so much from its life as from its afterlife.

(Benjamin 1992: 73; Translated by Harry Zohn)

(d) Just as expressions of life are connected in the most intimate manner with the living being without having any significance for the latter, a translation proceeds from the original. Not indeed so much from its life as from its "afterlife" or survival" [Überleben].

(Rendall 1997: 153) 


\subsubsection{Case 2}

(2) Ist doch die Übersetzung später als das Original und bezeichnet sich doch bei den bedeutenden Werken, die da ihre erwählten Übersetzer niemals im Zeitalter ihrer Entstehung finden, das Stadium ihres Fortlebens.

(Benjamin 1955: 51)

(a) Car la traduction vient après l'original et, pour les œuvres importantes, qui ne trouvent jamais leur traducteur prédestiné au temps de leur naissance, elle caractérise le stade de leur survie.

(Benjamin 2000a: 246-247; Translated by Maurice de Gandillac)

(b) Car la traduction est plus tardive que l'original, et pour les œuvres importantes, qui ne trouvent jamais le traducteur élu à l'époque de leur surgissement, elle marque le stade de leur survivance.

(Benjamin 1991: 152; Translated by Martine Broda)

(c) For a translation comes later than the original, and since the important works of world literature never find their chosen translators at the time of their origin, their translation marks their stage of continued life.

(Benjamin 1992: 73; Translated by Harry Zohn)

(d) Nonetheless the translation is later than the original, and in the case of the most significant works, which never find their chosen translators in the era in which they are produced, indicates that they have reached the stage of their continuing life [Fortleben].

(Rendall 1997: 153)

\subsubsection{Case 3}

(3) In völlig unmetaphorischer Sachlichkeit ist der Gedanke vom Leben und Fortleben der Kunstwerke zu erfassen.

(Benjamin 1955: 51-52)

(a) C'est, en effet, dans leur simple réalité, sans aucune métaphore qu'il faut concevoir pour les œuvres d'art les idées de vie et de survie.

(Benjamin 200a: 247; Translated by Maurice de Gandillac)

(b) C'est dans leur réalité nue, sans aucune métaphore, qu'il faut comprendre les idées de vie et de survivance pour les œuvres d'art.

(Benjamin 1991: 152; Translated by Martine Broda)

(c) The idea of life and afterlife in works of art should be regarded with an entirely unmetaphorical objectivity.

(Benjamin 1992: 73; Translated by Harry Zohn)

(d) The notion of the life and continuing life of works of art should be considered with completely unmetaphorical objectivity.

(Rendall 1997: 153)

\subsubsection{Cases 4 and 5}

(4-5) Und ist nicht wenigstens das Fortleben der Werke unvergleichlich viel leichter zu erkennen als dasjenige des Geschöpfe? Die Geschichte der großen Kunstwerke kennt ihre Deszendenz aus den Quellen, ihre Gestaltung im Zeitalter des Künstlers und die Periode ihres grundsätzlich ewigen Fortlebens bei den nachfolgenden Generationen. 
(a) Et, à tout le moins, la survie des œuvres n'est-elle pas incomparablement plus aisée à connaître que celle des créatures? L'histoire des grandes œuvres d'art connaît leur filiation à partir des sources, leur création à l'époque de l'artiste, et la période de leur survie, en principe éternelle, dans les générations suivantes.

(Benjamin 2000a: 247; Translated by Maurice de Gandillac)

(b) Et pour le moins, la survivance des œuvres n'est-elle pas incomparablement plus facile à reconnaître que celle des créatures? L'histoire des grandes œuvres d'art connait leur descendance à partir des sources, leur formation au temps de l'artiste, et la période de leur survivance principiellement éternelle dans les générations suivantes.

(Benjamin 1991: 152; Translated by Martine Broda)

(c) And indeed, is not the continued life of works of art far easier to recognize than the continual life of animal species? The history of the great works of art tells us about their antecedents, their realization in the age of the artist, their potentially eternal afterlife in succeeding generations.

(Benjamin 1992: 73; Translated by Harry Zohn)

(d) And isn't the continuing life of works incomparably easier to recognize than that of creatures? The history of great works of art knows about their descent from their sources, their shaping in the age of the artists, and the periods of their basically eternal continuing life in later generations.

(Rendall 1997: 154)

\subsubsection{Case 6}

(6) Dieses letzte heißt, wo es zutage tritt, Ruhm. Überzetzungen, die mehr als Vermittlungen sind, entstehen, wenn im Fortleben ein Werk das Zeitalter seines Ruhmes erreicht hat.

(Benjamin 1955: 52)

(a) Cette survie, lorsqu'elle a lieu, se nomme gloire. Des traductions qui sont plus que des transmissions naissent lorsque, dans sa survie, une œuvre est arrivée à l'époque de sa gloire.

(Benjamin 2000a: 247; Translated by Maurice de Gandillac)

(b) Cette dernière, lorsqu' elle vient au jour, se nomme gloire. Des traductions qui sont plus que des transmissions naissent quand dans sa survivance une œuvre a atteint le temps de sa gloire.

(Benjamin 1991: 153; Translated by Martine Broda)

(c) When this last manifests itself, it is called fame. Translations that are more than transmissions of subject matter come into being when in the course of its survival a work has reached the age of its time.

(Benjamin 1992: 73; Translated by Harry Zohn)

(d) Where it appears, the latter is called fame. Translations that are more than transmissions of a message are produced when a work, in its continuing life, has reached the age of its fame.

(Rendall 1997: 154)

\subsubsection{Case 7}

(7) Denn in seinem Fortleben, das so nicht heißen dürfte, wenn es nicht Wandlung und Erneuerung des Lebendigen wäre, ändert sich das Original.

(Benjamin 1955: 53) 
(a) Car dans sa survie, qui ne mériterait pas ce nom si elle n'était mutation et renouveau du vivant, l'original se modifie.

(Benjamin 2000a: 249; Translated by Maurice de Gandillac)

(b) Car dans sa survivance, qui ne mériterait pas ce nom si elle n'était transformation et renouveau du vivant, l'original se modifie.

(Benjamin 1991: 154; Translated by Martine Broda)

(c) For in its afterlife - which could not be called that if it were not a transformation and a renewal of something living - the original undergoes a change.

(Benjamin 1992: 74; Translated by Harry Zohn)

(d) For in its continuing life, which could not be so called if it were not the transformation and renewal of a living thing, the original is changed.

(Rendall 1997: 155)

\subsubsection{Case 8}

(8) Wenn aber diese derart bis ans messianische Ende ihrer Geschichte wachsen, so ist es die Übersetzung, welche am ewigen Fortleben der Werke und am unendlichen Aufleben des Sprachen sich entzündet, immer von neuem die Probe auf jenes heilige Wachstum der Sprachen zu machen [...]

(Benjamin 1955: 55)

(a) Mais, lorsqu'elles croissent de la sorte jusqu'au terme messianique de leur histoire, c'est à la traduction, qui tire sa flamme de l'éternelle survie des œuvres et de la renaissance indéfinie des langues, qu'il appartient de mettre toujours derechef à l'épreuve cette sainte croissance des langues, [...]

(Benjamin 2000a: 251; Translated by Maurice de Gandillac)

(b) Mais quand celles-ci ont cru jusqu'au terme messianique de leur histoire, c'est à la traduction, qui s'enflamme au contact de la survivance éternelle des œuvres et de la renaissance infinie des langues, quil revient de faire la preuve de cette sainte croissance des langues $[\ldots]$

(Benjamin 1991: 155; Translated by Martine Broda)

(c) If, however, these languages continue to grow in this manner until the end of their time, it is translation which catches fire on the eternal life of the works and the perpetual renewal of language. Translation keeps putting the hallowed growth of languages to the test: [...]

(Benjamin 1992: 76; Translated by Harry Zohn)

(d) But if languages grow in this way until they reach the messianic end of their history, then it is translation that is ignited by the eternal continuing life of the work and the endless revival of languages in order to constantly test this sacred growth of languages, [...]

(Rendall 1997: 157)

\subsubsection{Case 9}

(9) Freilich haben sie diese als solche kaum erkannt, vielmehr ihre ganze Aufmerksamkeit der Kritik zugewendet, die ebenfalls ein wenn auch geringeres Moment im Fortleben der Werke darstellt. 
(a) Certes ils ne l'ont guère connue en tant que telle, mais ont porté toute leur attention sur la critique qui représente elle aussi, mais à un moindre degré, un moment dans la survie de œuvres.

(Benjamin 2000a: 253; Translated by Maurice de Gandillac)

(b) Ils ne l'ont guère, il est vrai, reconnue comme telle, mais ont plutôt porté toute leur attention sur la critique, qui représente également, mais à un degré moindre, un moment de la survivance des œuvres.

(Benjamin 1991: 156; Translated by Martine Broda)

(c) To be sure, they hardly recognized translation in this sense, but devoted their entire attention to criticism, another, if lesser, factor in the continued life of literary works.

(Benjamin 1992: 77; Translated by Harry Zohn)

(d) The Romantics, of course, hardly recognized the significance of translation, turning their attention instead entirely toward criticism, which also represents a genuine, though narrower, element in the work's continuing life.

(Rendall 1997: 158)

\subsection{Findings}

Below is a table which summarizes the solutions given above, for each of the four translators.

TABLE 1

Translations of Überleben and Fortleben by de Gandillac, Broda, Zohn, and Rendall.

\begin{tabular}{|l|l|c|c|c|c|}
\hline Case 1 & >Überleben< & «survie» & «survie» & afterlife & $\begin{array}{c}\text { RENDALL } \\
\text { "afterlife" or } \\
\text { "survival” } \\
\text { [Überleben] }\end{array}$ \\
\hline Case 2 & Fortleben & survie & survivance & continued life & $\begin{array}{c}\text { continuing life } \\
\text { [Fortleben] }\end{array}$ \\
\hline Case 3 & Fortleben & survie & survivance & afterlife & continuing life \\
\hline Case 4 & Fortleben & survie & survivance & continued life & continuing life \\
\hline Case 5 & Fortleben & survie & survivance & afterlife & continuing life \\
\hline Case 6 & Fortleben & survie & survivance & survival & continuing life \\
\hline Case 7 & Fortleben & survie & survivance & afterlife & continuing life \\
\hline Case 8 & Fortleben & survie & survivance & (eternal) life & continuing life \\
\hline Case 9 & Fortleben & survie & survivance & continued life & continuing life \\
\hline
\end{tabular}

\subsection{Analysis}

A quick glance at the variety of choices by which the four translators translated Benjamin's Fortleben, and their divergent methods of marking the difference between Fortleben and Überleben, immediately confirms that we are here looking at a textual element that must have caused several moments of pre-hermeneutic uncertainty in the translators. 
According to the online DWB (Deutsches Wörterbuch) there is a distinct difference in usage of the verbs from which the nouns Überleben and Fortleben are derived. The verb überleben is used in its generic meaning to express the idea of living longer than something or someone, and by extension in contexts referring to metaphysics - one of the examples is a sentence from Dietrich v. d. Werder: "du aber, Herr, wirst überleben die Zeit, den Todt, die ganze Welt."' The verb fortleben, on the other hand, expresses the idea of continuing to live, as for example in Schiller's sentence "der entzwei geschnittene Wurm lebt noch fort" 7 but the DWB does not feature any examples of a transcendental meaning for fortleben. The German preposition fort, which is etymologically related to the English forth (as in go forth) and is the same as the Dutch voort (as in voortleven) gives the noun Fortleben its dynamic meaning of continuing life or life continuing into the future. In short, as the examples which feature in the DWB show, in German überleben is the metaphysical counterpart of fortleben. ${ }^{8}$

De Gandillac's translation shows that he chose not to deal with the difference between Überleben and Fortleben on a lexical level, although he must have recognised it, since he copied Benjamin's quotation marks around the first term. But de Gandillac then translated both Überleben and Fortleben by the same survie, continuing with this choice for the remainder of all the occurrences of Fortleben. The result of this is that in this version the idea of rising into a higher realm is more prominent than the idea of living-on or continuing life, as Derrida's reading has already confirmed. Meanwhile, in Benjamin's text, it is the idea of continuing life (Fortleben), and not of survival (Überleben) which dominates the semantic tension, even though conceptually the essay's messianic message seems to contradict this lexical preference. It is important to note that the recently republished translation by de Gandillac was revised by Rainer Rochlitz, who retains the choices made by de Gandillac concerning Überleben and Fortleben (see Benjamin 2000a).

Secondly, Martine Broda (whose translation, incidentally, is not easy to come by), opts to acknowledge and match the original distinction by creating a similar lexical difference in her translation. She uses the same quotation marks and the direct translation of $>$ Überleben $<$ («survie»), and then consistently chooses survivance to translate Fortleben. The Trésor de la langue française's entries for survie and survivance greatly overlap, especially for the general idea of "Maintien du souvenir ou de l'œuvre de quelqu>un, après sa mort, dans la mémoire d`une communauté," which might explain why de Gandillac did not choose survivance. Nonetheless, in its nonfigurative meaning survie has stronger connotations of in / after / in spite of death, and the meanings of "fait de rester en vie au delà d'un terme où normalement intervient la mort" and "fait de se maintenir en vie dans un environnement naturel mortifère" do not apply to survivance. Survie therefore more strongly connotes living above or beyond death, and corresponds better to Überleben, whereas survivance, with its grammatical form as a nominalised present participle, is more dynamic and works better for the equally more dynamic Fortleben. Broda thus acknowledges the importance of the distinction in Benjamin's text and reproduces it both lexically and conceptually in her translation.

Thirdly, as the table shows, Harry Zohn's choices follow no discernible rationale, as he begins by translating Überleben by afterlife (instead of survival), but then also translates Fortleben as afterlife, while another instance of Fortleben is translated as 
survival. Whether this means that Zohn struggled with the tension between the two terms or that he simply ignored it is difficult to say, but the resulting muddle obscures the source text distinction from the reader of the translation, since Zohn effectively makes it invisible by covering it up by a series of near-synonyms.

Fourthly, a very clear signpost that the pair Fortleben and Überleben are a source of uncertainty can be found in Rendall's solution for Case 1: by proposing an alternative Rendall shows his own oscillation between two possible meanings for Überleben, and by adding the original terms in square brackets, he allows his readers to judge the difference for themselves. Rendall's further choices are a consistent use of continuing life (instead of Zohn's continued life) which resembles Broda's choice of survivance, in that the -ING form expresses the dynamism of the German preposition fort, which I have explained above. Rendall thus sheds light on the source of hermeneutic uncertainty by adding the German words in square brackets in its first occurrence, and further highlights the tension between the terms by sticking to the same expression for all the occurrences of Fortleben.

To put it in a nutshell, each pair of translations contains one version which does not mark the difference between Fortleben and Überleben either lexically or otherwise, and one which does. We can therefore organise the four translations in terms of translator visibility, ranking them from the most visible to the least visible, beginning with Rendall's foregrounding of Überleben, his highlighting of the tension between Überleben and Fortleben, and his choice of a lexical equivalent pair of terms, over Broda who acknowledges the difference by translating it with a similar lexical pair in French, to de Gandillac who recognises the hermeneutic difficulty but ignores it in his translation, and ending with Zohn, who seems not only to ignore its importance but effectively conceals it by opting for a number of unnecessary lexical variations.

Interestingly, it is the translations that make the least affirmative or visible choices to translate the pair of terms, that is, Zohn's for English and de Gandillac's for French, which are the most widely diffused and the most widely read, whereas Rendall's and Broda's, who marked it lexically and even foregrounded it, remain the lesser-known and lesser-diffused versions. That Broda's and Rendall's alternative translations existed when the canonical translations were republished (as I indicated earlier, de Gandillac's was republished in 2000 and Zohn's last appearance was in the Venuti Reader (see Benjamin 2000b), makes this all the more frustrating, and Rendall's suggestion that such things happen because of copyright issues (Rendall 2000: 23) is not much of a consolation.

\section{Conclusions}

As the above analysis has shown, a fundamental idea in a pivotal essay in Translation Studies has caused moments of pre-hermeneutic and hermeneutic uncertainty in its translators, critics and meta-critics alike, and continues to feature in the canonical translations of that essay in a way that perpetuates the uncertainty surrounding its meaning and therefore the meaning of the text as a whole, despite the vast amount of criticism generated by Benjamin's text and the fact that the quality of the translations is addressed in these critical discussions.

Examining how different translators have dealt with a case of hermeneutic uncertainty in existing translations, and how their different solutions can be placed 
on a sliding scale of translator visibility, can teach students something about the ubiquitous uncertainty linked to choice in translation. Moreover, if students are allowed to consider that it is apparently possible for famous translators to get away with hermeneutic bulldozing (in the case of de Gandillac) or hermeneutic confusion (in the case of Zohn) and still have their translations republished, they might feel a little less awestruck when faced with what at first seems like an impenetrable source text difficulty. If a sense of irony is allowed to be a part of a translator's make-up this might be a comforting thought for students who fear hermeneutic uncertainty and are destabilized by it. It should obviously not warrant carelessness on their behalf, but it might help to remind them that hermeneutic uncertainty has affected the work of some of the most illustrious translators of some of the most well-known texts in the field of translation studies.

Moreover, as the more theoretical part of this article has aimed to show, students can build on their awareness of the fact that we cannot escape our ontological horizon, and that whenever we apprehend the world we draw on things that are already known to us, through analogy or simply because those thoughts dwell in our minds as Gadamerian prejudices. Everyone is familiar with the idea that we anticipate meaning when faced with a text, i.e. that there is already something there. Most people who have ever thought about how they apprehend the world will agree with Gadamer when he says that "[a] person who is trying to understand a text is always projecting" (Gadamer 2004: 269). This knowledge, whether presented in the philosophical form proposed in this article or in another shape, should be part and parcel of a training translator's knowledge and know-how.

In the end, the above examples of illustrious and not-so-illustrious translators' handling of a case of hermeneutic uncertainty shows that

[h] ermeneutics may even work as a research paradigm, when the question is tackled, which kind of learning content is adequate for the future translators, or which are the factors of translation competence. (Stolze 2010: 145)

I hope to have demonstrated that discussing the existence of pre-hermeneutic prejudice both as a philosophical concept and as found, for instance, in translational and editorial policies which reflect expressions of that prejudice, may provide teachers of translation and translation theory with an opportunity to instil in their students a sense of craftsmanship that includes hermeneutic uncertainty as a part of their future working life. Such consciousness-raising can also provide the comforting knowledge that when published translators struggle with hermeneutic uncertainty, some show humility, while others take a more cavalier stance, which may go some way to help students to better prepare for their first lonely "Eh? moments" and go through these not in anxiety, but with the confidence that these are an integral part of their chosen profession.

\section{NOTES}

1. Certificat d'aptitude au professorat de l'enseignement du second degré.

2. Pearsall, Judy, ed. (1998): hermeneutics. The New Oxford Dictionary of English. Oxford: Clarendon Press, p. 858.

3. Benjamin literally affirms the messianic character of translation in the following sentence: "Translation keeps putting the hallowed growth of languages to the test: How far removed is their 
hidden meaning from revelation, how close can it be brought by the knowledge of this remoteness?" (Benjamin 1992: 76).

4. Le nouveau recueil. À moment donné: Dossier Martine Broda. (Last update: December 2014).

Visited 15 April 2015, <http://www.lenouveaurecueil.fr/BRODA/Brodadossier.html>.

5. In all of the examples, the emphasis is ours.

6. "but you, Lord, will survive time, death, and the whole world" (our translation).

7. "worms continue to live / live on even after they have been cut in two" (our translation).

8. Grimm, Jacob and Grimm, Wilhelm (1854/2015): Deutsches Wörterbuch. Trier: Universität Trier. Visited 15 April 2015, <http://dwb.uni-trier.de/de/die-digitale-version/online-version>.

9. Trésor de la langue française informatisé. Visited 10 April 2015, <http://atilf.atilf.fr/tlf.htm>.

\section{REFERENCES}

BeLlos, David (2010): Halting Walter. Cambridge Literary Review. 1(3):207-220.

Benjamin, Walter (1923): Die Aufgabe des Übersetzers. In: Charles Baudelaire. Tableaux parisiens. Heidelberg: Verlag von Richard Weissbach, VI-XVII.

Benjamin, Walter (1955): Die Aufgabe des Übersetzers. Siegfried Unseld, ed. Walter Benjamin, lluminationen: Ausgewählte Schriften, I. Frankfurt: Suhrkamp, 50-62.

Benjamin, Walter (1971): CEuvres. 1, Mythe et violence. (Translated by Maurice De Gandillac). Collection Les Lettres Nouvelles. Paris: Denoël.

Benjamin, Walter (1991): La tâche du traducteur (Translated by Martine Broda). Poł sie (Poésie) 55. Paris: Belin, 150-158.

Benjamin, Walter (1992): The Task of the Translator. (Translated by Harry ZoHn). In: Rainer Schulte and John Biguenet, eds. Theories of Translation. An Anthology of Essays from Dryden to Derrida. Chicago: The University of Chicago Press, 71-82.

Benjamin, Walter (2000a): La tâche du traducteur (Translated by Maurice DE Gandillac, revised by Rainer Rochlitz). In: Walter Benjamin CEuvres. (Translations by Maurice DE Gandillac, Rainer Rochlitz and Pierre Rusch). Vol.1. Paris: Gallimard, 244-262.

Benjamin, Walter (2000b): The Task of the Translator. (Translated by Harry ZoHN). In: Lawrence Venuti, ed. The Translation Studies Reader. London: Routledge, 15-23.

Derrida, Jacques (1985): The Ear of the Other. Otobiography, Transference, Translation. Texts and Discussions with Jacques Derrida. (Translated by Peggy Kamuf), Christie McDonald, ed. Lincoln/London: University of Nebraska Press.

Derrida, Jacques (1987): Des tours de Babel. Psyché: Inventions de l'autre. Paris: Galilée.

Derrida, Jacques (1990): Du droit à la philosophie. Paris: Galilée.

Derrida, Jacques (1997). Of Grammatology. (Translated by Gayatri C. SPIVAK). Corrected edition. Baltimore: Johns Hopkins University Press.

Feynman, Richard (1955): The Value of Science. Engineering and Science. 19(3):13-15.

GadAmer, Hans Georg (2004): Truth and Method. $2^{\text {nd }}$ revised edition. (Translation revised by Joel Weinsheimer and Donald G. Marshall). London: Continuum.

Gleick, James (1992): Genius. The Life and Science of Richard Feynman. New York: Vintage Books.

Heidegger, Martin (2008): Being and Time. (Translated by John Macquarrie and Edward RoBinson with a new foreword by Taylor CARMAN). New York: Harperperennial.

INGRAM, Susan (1997): The Task of the Translator: Walter Benjamin's Essay in English, a Forschungsbericht. TTR. 10(2):207-233.

Kounios, John and Beeman, Mark (2009): The Aha! Moment. The Cognitive Neuroscience of Insight. Current Directions in Psychological Science. 18(4):210-216.

Mulhall, Steven (1996): Heidegger and Being and Time. London: Routledge.

RENDALL, Steven (1997): The Translator’s Task, Walter Benjamin (Translation). TTR. 10(2):151165.

Rendall, Steven (2000): A note on Harry Zohn's translation. In: Lawrence Venuti, ed. The Translation Studies Reader. London: Routledge, 23-25.

ShaH, Idries (1968): Caravan of Dreams. London: The Octagon Press. 
SpIVAK, Gayatri C. (1997): Translator's Preface. In: DerRIDA, Jacques. Of Grammatology. (Translated by Gayatri C. SpIVAK). Corrected edition. Baltimore: Johns Hopkins University Press. p. ix-ixxxvii.

Stolze, Radegundis (2010): Hermeneutics and Translation. In: Yves GambIER and Luc VAN Doorslaer, eds. Handbook of Translation Studies. Vol. 1. Amsterdam: John Benjamins, 141-146.

Subramaniam, Karuna, Kounios John, Parrish Todd B., and Jung-Beeman Mark (2008): A Brain Mechanism for Facilitation of Insight by Positive Affect. Journal of Cognitive Neuroscience. 21(3):415-432. 